ARTIGOS

\section{ARE THE FINANCIAL SERVICES' CUSTOMERS TRULY LOYAL? AN INVESTIGATION IN THE POR- TUGUESE PRIVATE BANKING SECTOR}

\begin{abstract}
This study aims at understanding how loyalty is formed and which variables contribute the most to build strong and stable relationships with customers. This research is based on a sample of 403 customers of private banks in Northern Portugal. Data collection was made using structured questionnaire, applied directly to these customers. A Multiple Linear Regression modelling approach was adopted to assess the proposed hypothesis. The results of this investigation show that the relationships between customers and their main banks seem to be based on a more transactional logic. It is based on the perceived value and the switching costs, and satisfaction remains as the main driver. Nevertheless, there seems to be room for further exploitation of the psychological variables such as emotions, once they have shown an important role on satisfaction.
\end{abstract}

Keywords: Relationship marketing. Loyalty. Satisfaction. Behaviour. Bank.

\section{INTRODUCTION}

The general objective of this research is to identify and understand the antecedents of loyalty among customers and private banking. Relationship Marketing assumes that maintaining customer's loyalty is much more beneficial than spending time and resources to fight for new customers (BERRY, 2002). Fornell and Wernerfelt (1987), Zeithaml, Berry and Parasuraman (1996) also argue that the relative costs of customer retention are substantially lower than customer acquisition.

Satisfied customer comments with at least three potential customers of their relations, his satisfaction with the services or products of the company, recommending them the brand or the service. On the other hand, an unsatisfied customer comments negatively with at least nine customers his dissatisfaction with the service or product purchased. In this situation, a potentially serious problem for the company's image can be created, with consequences for the relationship and turnover.

Companies in general and banks in particular, have 
assumed the importance of establishing long-term relationships with satisfied customers, changing happy customers into loyal customers (BERRY, 2002; HENNIG-THURAU; GWINNER; GREMLER, 2002). However, several studies show that a satisfied customer is not necessarily loyal (REICHHELD, 1994; JONES; SASSER, 1995). While for some customers, loyalty is exclusively due satisfaction with the bank, there are other customers for whom loyalty is a function of other variables (VERHOEF; LANGERAK, 2002). Most of the literature in this field shows loyalty as a result of a sum of determinants that can be found on relationship marketing literature (PRITCHARD; HAVITZ; HOWARD, 1999; JOHNSON et al., 2001; MATTILA, 2001).

Competition in the banking sector is increasing and financial firms (old and new operators) compete fiercely for their customers. Banks have to deal with the customer's turnover, as well as to deal with customers who have their banking business spread over several banks (ADAMSON; SHINE, 2003). Relationship marketing seems to be the main approach of a differentiation strategy for banks and loyalty appears to be essential for the survival of business services (REICHHELD, 1994). This fight for loyalty in financial services triggered a large and detailed investigation amongst academicians and practitioners. The investigation on loyalty has focused on its impact on performance (GRÖNROOS, 1994), in the costs of non-loyalty (REICHHELD; SASSER, 1995) or on identifying its antecedents (KOTLER, 1991, 1992; GUMMESSON, 1987, 1994; MORGAN; HUNT, 1994; GRÖNROOS, 1994). At the same time, understanding the relational process seems to be a path for success for organizations that wish to strengthen ties with their consumers, using strategic relationship as a differential (ANJOS NETO; MOURA, 2004).

The study proposed here falls within the relationship field, with a particular focus on customer relationships. It aims to identify the variables that behave as true determinants of loyalty. The operationalization of this study has a quantitative nature, supported by a structured questionnaire and aims to collect the perceptions of customer's relations to their main banks, in the North of Portugal.

\section{RESEARCH BACKGROUND AND HYPOTHESIS DEVELOPMENT}

The conceptual model tested in this study is presented in Figure 1. This model basically investigates the influence of trust, satisfaction and its antecedents on loyalty. This model integrates a wide range of direct and non-direct loyalty determinants to promote a better comprehension of customer loyalty on the banking industry.

Not all customers are seeking for long-term relationships but, on the other hand, all companies need to meet a set of loyal customers that can contribute to business stability and sustainability. Jones and Sasser (1995) suggested that customer loyalty is the best predictor of long-term financial performance. Thus, understanding how and why customers are taken to develop this sense of loyalty has become one of the crucial issues for investigation and management (PRITCHARD; HAVITZ; HOWARD, 1999). Loyalty is the main objective of relationship marketing and it is often perceived as being the actual relationship marketing (SHETH, 1996). Loyalty involves the conquest, maintenance and deepening of the relationships with customers, so loyalty is the essence of the broader relationship marketing (REICHHELD; SCHEFTER, 2000).

Jacoby and Chestnut (1978), Solomon (1992) and Dick and Basu (1994), highlighted the two different, but complementary dimen- 
sions of loyalty, and Beerli, Martin and Quintana (2004) showed their different roles: attitudinal loyalty and behavioral loyalty. According to the same authors, the first dimension is considered the true loyalty to the brand, as it reflects a conscious decision to purchase and repeat purchase, accompanied by a positive attitude which implies in a high degree of commitment to the brand. The second dimension is loyalty based on inertia, where the product or service of a particular brand is acquired only by habit. The consumer makes less effort for choice and will not hesitate to switch it for another brand if there is a convenient reason for the decision.

Shoemaker and Lewis (1999, p. 349) argue that customers are truly loyal when "[...] they feel secure that a particular company can better meet their needs, so that competition is virtually excluded of its universe of options. These customers buy almost exclusively from this company". This definition illustrates the emotional aspects of loyalty. According to Bowen and Shoemaker (2003), the emotional bonds between customers and brands or companies are like an affective commitment, profusely referenced in the literature.

Loyalty makes customers communicate their positive experiences with their friends. Friends and also general users are seen as credible sources of information about products/services (COLLIANDER; DÖHLEN, 2011). The positive word of mouth (WOM) has a powerful impact on the decision-making process, according to Nguyen and Le Blanc, (2001). He states that in a market with numerous communicators and sources of communication, WOM remains a source of information highly reliable and secure.

Gremler and Brown (1996) as well as El-Manstrly et al. (2011) claim that loyal customers are more likely to buy more and make more positive recommendations to friends and acquaintances, as well as resist more the competitive offerings. Finally, loyalty seems to be a very important driver of long-term profitability (JAFARNEJAD; SHAROUDI; FARZANEH, 2012) and customer lifetime value (QI et al., 2012).

\subsection{THE ROLE OF SATISFACTION}

According to Howard and Sheth (1969, p. 175) satisfaction "is the buyer's cognitive state of being adequately or inadequately rewarded for the sacrifices they made." At the same time, for Miller (1977, p. 114) "satisfaction is the result of the interaction between the level of product performance expectations and perceived performance." Day $(1977$, p. 26) states that "satisfaction is a conscious evaluation or judgment which issues the consumer about the goodness of the results of a product or company, or in adapting the product or company to its use or purpose" and Hunt (1977, p. 77) believes that "satisfaction is an assessment as to whether the buying experience or use was at least as good as it was supposed to be". Within the banking system, satisfaction creates an opportunity for brands of excellence, to the extent that satisfied customers can directly influence their friends and acquaintances (COLLIANDER; DÖHLEN, 2011), producing a positive word of mouth.

Garbarino and Johnson (1999) stated that commitment could be a mediating variable between satisfaction and loyalty. Satisfaction influences the confidence and commitment of customers in the context of services (BLOEMER; ODEKERKEN-SCHRÖDER， 2002; FRANCISCO-MAFFEZZOLLI, 2007) and leads to the establishment and consolidation of long-term relationships. Consequently, the following hypotheses have been inferred:

$\mathrm{H1}$ : There is a positive impact of satisfaction on loyalty

$\mathrm{H} 2$ : There is a positive impact of satisfaction on Commitment

\subsection{THE ROLE OF TRUST}

Trust is a concept that has been treated in several different fields, particularly in the marketing field (MOORMAN; DESHPANDÉ; ZALTMAN, 1993; MORGAN; HUNT, 1994; TAX; BROWN; CHANDRASHEKARAN, 
1998; GARBARINO; JOHNSON, 1999; SIRDESHMUKH; SINGH; SABOL, 2002; BALL; COELHO; MACHAS, 2004). It is the belief of the parties in the reliability and integrity of the negotiating partner (MORGAN; HUNT, 1994). Dwyer, Schurr and Oh (1987) define trust as the expectation that the provider of services or products is reliable, fulfilling their promises. According to Gremler and Brown (1998) and Bansal Taylor and James (2005), trust is generally seen as a critical element in the development of commitment and customer loyalty.

Bloemer and Odekerken-Schröder (2002) and Francisco-Maffezzolli, (2007), introduce several examples that confirms that satisfaction influences the customer trust in the context of services, including the ones with products and services offered in the financial sector. The customer satisfaction received in successive customer purchases, increases the perceptions of reliability of the provider, strengthening positive attitude defined as trust (MORGAN; HUNT, 1994). Consequently, the following hypotheses have been deducted

H3: There is a positive impact of trust on loyalty

H4: There is a positive impact of trust on commitment

H5: There is a positive impact of satisfaction on trust

\subsection{THE ROLE OF COMMITMENT}

The impacts of commitment in consumer behaviour are neither clear nor peaceful in the literature. There is, however, a great convergence between commitment and loyalty, as both may represent different dimensions of a broader concept of loyalty (PRADO; SANTOS, 2003). Commitment is a concept treated profusely in the distribution of channels literature, and it was within that literature that the concept emerged (MARTIN; GOODELL, 1991).

Commitment is recognized as an essential ingredient for establishing and maintaining long-term relationships (DWYER; SCHURR;
OH, 1987; ANDERSON; WEITZ, 1992). Somehow, it is considered a central and ubiquitous concept in all success relational exchanges between the company and its customers (MORGAN; HUNT, 1994).

Some authors consider equivalent definitions of commitment and loyalty, as Oliver (1997, 1999), (SHETH, 2000; PATTERSON; WARD, 2000; CHAUDHURI; HOLBROOK, 2001), while other authors consider these constructs independently (STORBACKA; STRANDVISK; GRONROOS, 1994). However, recent literature presents commitment as an antecedent of loyalty, as an attitude that leads to continuance, to the consolidation of a long lasting relationship (LARIVIERE et al., 2014; SINGH H., 2015).

There are several empirical studies that show that trust determines affective commitment (PRADO; SANTOS, 2003) in services in general and banking in particular (BLOEMER; ODEKERKEN-SCHRÖDER，2002; MARQUES, 2003; FRANCISCO-MAFFEZZOLLI, 2007). At the same time, every satisfactory moment, boosts the customers' trust in the Service Provider (GANESAN, 1994; FRANCISCO-MAFFEZZOLLI, 2007), including new customers (MÜCKENBERGER, 2001) as well as transactional customers (GARBARINO; JOHNSON, 1999). This leads to the following hypothesis:

H6: There is a positive impact of commitment on loyalty

\subsection{THE ROLE OF SWITCHING COSTS}

In the context of a relationship, there are some factors that act as barriers to exit this relationship. These factors or barriers to exit are called switching costs. According to Lee and Cunningham (2001) are the costs that the consumer incurs by switching supplier, he would not incur if it remained in the current supplier. The switching costs are all the expected losses, resulting from the terminus, as well as the result of the perceived lack of alternative sup- 
pliers (MORGAN; HUNT, 1994). Switching costs or costs of switching a provider are taken into account by the customer in any exchange situation. According to Bhattacharya and Bolton (2000) financial services, by their nature, involve high switching costs. So, the following hypothesis is proposed:

H7: There is a positive impact of switching costs on loyalty.

\subsection{THE ROLE OF MONETARY COSTS}

The monetary cost may be an indicator of the amount of monetary sacrifice required to purchase a product or service and thus, an indicator of the quality of the product. Higher financial costs are typically associated with higher perceived quality and, consequently, to a greater predisposition to buy (DODDS; MONROE; GREWAL, 1991).

As the financial cost of a product or service increases, superior qualities of the product or service are perceived (DODDS; MONROE; GREWAL, 1991; CHAPMAN; WAHLERS, 1999; GUARITA; URDAN, 2006). At the same time, as these costs increase, the predisposition to buy may decrease. They are seen as the sacrifice one has to do to buy something, with a negative impact on perceived value. In the context of banking, the financial cost has a negative effect on perceived value, defined as the relationship between perceived quality and perceived monetary and non-monetary sacrifice (GUARITA; URDAN, 2006).The financial cost of a product or service has a negative impact on the customer's satisfaction on supermarkets (DAVIES et al., 2001) as well as on bank's private customers (LEVESQUE; MCDOUGALL, 1996; WINSTANLEY, 1997). Mittal, Kumar and Tsiros (1999), concluded that on the customer's repurchase assessment, the price received special attention when compared with satisfaction. Some studies (THUNMAN, 1992; LEVESQUE; MCDOUGALL, 1996; DUNKELBERG, 2000; JOHNSON et al., 2001; GUARITA; URDAN, 2006) high- light the importance that the pricing policy plays in customer relationships with financial institutions. To Thunman (1992) the economic link is the aspect with the most important impact in the relationship between banks and their customers. However, economic links, such as loyalty programs, are considered the most fragile relationship stimulus and may lead to a spurious loyalty (BERRY, 2000). This conclusion may be due to the belief that economic links are considered the most fragile basis of a relationship (BERRY, 2000). According to DuPont (1998) monetary incentives are truly transactional incentives.

\subsection{THE ROLE OF NON-MONETARY COSTS}

There are several costs that generally present a non-monetary nature. Time, effort, cost and sacrifice to seek alternative suppliers for the same product or service may be perceived as non-monetary costs. Therefore, all that can be added to the product or service to reduce time, effort and cost of searching for alternative suppliers can reduce the perceived sacrifice and hence increase the customer perceived value (ZEITHAML, 1988).In the relationship between customers and their main bank, non-monetary costs have a negative effect on perceived value. In the banking industry, the non-monetary sacrifice is closely linked to the time lost on the bank, during the negotiations of credit or other banking operations, as well as the negotiation of guarantees or collateral contracts with banks (GUARITA; URDAN, 2006). However, Cronin, Brady and Hult (2000), state that service consumers seem to value more the perceptions of quality than the costs associated with its acquisition. Consequently, the higher the costs the less is the satisfaction and higher is the willingness to break the relationship, (BOWEN; SHOEMAKER, 2003) and reduce loyalty (AYDIN; ÖZER, 2005). So, the following hypothesis can be inferred: 
H8: There is a negative relationship between monetary costs and satisfaction with their main bank.

H9: There is a negative relationship between non-monetary costs and the satisfaction with their main bank.

\subsection{THE ROLE OF PERSONAL RELA- TIONSHIPS}

The concept of personal relationships is the perceived quality of interaction between the customer and the banking partner, usually with the account manager, responsible for a more or less personalized supervision (COLGATE; DANAHER, 2000). In the context of relationship marketing, personal interactions are a crucial element in the particular case of services marketing (CROSBY; EVANS; COWLES, 1990). According to Reichheld (1993) the company's employees are the ones that build the bonds of trust, commitment and satisfaction with customers. Thus, when these employees leave the company, these bonds can be broken, decreasing satisfaction, commitment and trust.

In the banking industry, where trust is a critical issue for customer's relationships, the contact employees, usually the account managers, are often considered more critical to the maintenance of the relationship with the customers, than when interaction occurs with other nonfinancial services (GANESH; ARNOLD; REYNOLDS, 2000). The additional value provided by monitoring, counselling and for financial advisory services provided to customers, strengthens, expressively, satisfaction, trust, commitment and also customer loyalty (BALL; COELHO; MACHAS, 2004). The frontline employees as well as their specific skills are often a critical determinant for the customer's decision to buy the service or not (GANESH; ARNOLD; REYNOLDS, 2000). Colgate and Lang (2003) suggest that a relationship manager, who is perceived by customers as a competent one, provides higher levels of relationship quality and higher levels of satisfaction, compared to the level of satisfaction felt by custo- mers who have no manager assigned. So, the following hypotheses are proposed:

H10: There is a positive impact of relationship quality on loyalty

H11: There is a positive impact of relationship quality on trust

H12: There is a positive impact of relationship quality on satisfaction

H13: There is a positive impact of relationship quality on commitment.

\subsection{THE ROLE OF DEPENDENCE}

Dependence can be seen as the degree to which customers need a specific relationship to achieve their objectives and satisfy their needs. It is the assistance needed to meet personal needs in terms of finances, emotions, or the safety and security of everyday attention, according to Glanze and Goldenson, (1984). Transactions supported in a spirit of long-term partnership have higher perceived degree of dependence between the partners, greater degree of communication between them, as well as a greater sense of trust and commitment. A higher dependence on one supplier for absence and / or poor availability of competing offers also creates a favourable environment to a greater commitment and loyalty between partners (KUMAR; SCHEER; STEENKAMP, 1995; GEYSKENS et al., 1996; ALMEIDA; COELHO; COELHO, 2004; SLONGO; MÜSSNICH, 2005). For that matter, the following hypothesis has been developed

H14: There is a positive relationship between dependence and loyalty

\subsection{THE ROLE OF EMOTIONS (POSI- TIVE AND NEGATIVE)}

Relationships cannot exist without emotional content, according to Berscheid, Snyder and Omoto (1989) and they are predictors of customer's satisfaction and loyalty in several contexts (BARNES, 1997). According to 
Prado (2004), after confirming the influence of emotional variables as impacting customer satisfaction and loyalty, emotions have become an integral part of the evaluation process on relationships. These emotions began to be integrated into models investigating customer loyalty (SIERRA; MCQUITTY, 2005). Moreover, Laran and Espinoza (2004) conclude that positive emotions positively influence customer satisfaction and negative emotions affect it negatively. Consequently, the following hypotheses were formulated:

H15: There is a positive impact of positive emotions on satisfaction.

H16: There is a negative impact of negative emotions on satisfaction

\subsection{THE ROLE OF IMAGE AND THE IMPACT ON SATISFACTION}

By creating a positive feeling about the company, the corporate image creates values for customers and it is strongly related to the physical and behavioural attributes of the corporation, such as Architecture, products and services offered as well as service quality and other inherent attributes. This feeling perceived by customers can also be transferred to third parties as a result of the interactions with the company and of the word of mouth produced (NGUYEN; LEBLANC, 2001). Empirical studies confirm the influence of satisfaction on the image of a company's virtual environment but in the context of services, the image has a direct impact on customer satisfaction (FERRAND; VECCHIATINI, 2002; HART; ROSENBERGER, 2004). In the banking industry, in particular, the corporate image has a major impact on customer satisfaction (BALL; COELHO; MACHAS, 2004). The following hypothesis is then proposed:

H17: There is a positive relationship between the perceived image and satisfaction

\subsection{THE ROLE OF CREDIT}

Winstanley (1997) concluded that the availability of credit and the quality of the relationship with the manager are the most important variables and those with the greatest impact on customer satisfaction in the banking industry. Still, to this author, the bank's customers associate the act of lending money to their main services. At the same time Madill et al. (2002) state that the credit has a relevant importance in customer satisfaction. Consequently, the availability of credit, in its different offers is one of the main concerns of private banking customers, so it was decided to introduce it in this investigation model. Thus, the following hypothesis can be inferred:

H18: There is a positive relationship between the credit available to private customers and satisfaction with their main bank

\subsection{THE ROLE OF PERSONAL CON- TACTS VERSUS VIRTUAL CON- TACTS}

Talking about relationship marketing and loyalty, it could hardly pass by the type of relationship customer maintains with his main bank, especially if it is more personal or rather virtual. Personal relationships, particularly with the account manager, can make all the difference in a relationship strategy. According to Dwyer, Schurr and Oh (1987, p. 12) personal contacts are very important in the socialization between customer and his bank, arguing "relational exchanges can become complex, personal, revealing the non-economic satisfaction and involving social exchange". Similarly, Solomon et al. (1985, p. 100), states that "in situations of pure service ... customer satisfaction and their repurchase intentions can only be determined by the quality of the staff meeting." However, models on remote banking, developed by retail banks in the UK, revealed a high rate of success in customer satisfaction $(90 \%$ satisfaction), according to a central bank sur- 
vey. Other banks quickly replicated this rate of success in customer satisfaction, like the historic HSBC. The success continued with the implementation of the program of dissemination of ATMs (MARR; PRENDERGAST, 1983), which confirmed that the variables determining the success of the technologies were the convenience of hours of use, place (any place to access) convenience and ease of use. The biggest problem is that the limits of the technology that customers accept as necessary are not known, i.e., what is the level of technological distance relationship that optimizes the customer loyalty with the bank. This will also be a major issue in the decision to allocate more resources to deepen relational services, foreseeing higher return on long-term relationships with customers. So, the following hypothesis is proposed:

H19: There is a relationship between the nature of the contact (personal / non-personal) and satisfaction.

\subsection{THE ROLE OF PERCEIVED VALUE}

The value perceptions result from the difference between perceptions of quality and sacrifice. Satisfaction is created when the perceived value, in the customer's perspective, meets or exceeds the expectations for value (MORGAN; HUNT, 1994). The customer value is the result of what customer receives - such as quality, benefits or utilities - and he effort invested to acquire and use a product - such as price or sacrifice (WOODRUFF, 1997). Value results from a comparison based on a standard rating, on a rational approach, which can be made without the requirement of an affective component (OLIVER, 1999). Therefore, value is considered an important element in relationship marketing (RAVALD; GRÖNROOS, 1996). Value is generated and perceived by customers in their own internal processes. Consumers and customers use their internal processes of value assessment to interact with vendors (GRÖNROOS, 2000). Moura, Gomes and Moura (2005) confirm that the research conducted in the services sector have shown that perceived value is a direct determinant of satisfaction, trust and commitment in the banking industry (BALL; COELHO; MACHAS, 2004) which are, in turn, important drivers of loyalty. Sirdeshmukh, Singh and Sabol (2002) argue that the empirical evidence shows that the perceived value exerts an influence on customer loyalty. The repurchase intentions and repeated buying behaviour are positively and significantly associated with perceived value (BLACKWELL; ENGEL; KEGERREIS, 1996; CHAPMAN; WAHLERS, 1999; CHOI et al., 2004).

The following hypothesis was then proposed:

H20: There is an impact of perceived value on Relationship on Commitment

$\mathrm{H} 21$ : There is an impact of perceived value of Relationship on Trust

The proposed investigation model is as follows: 


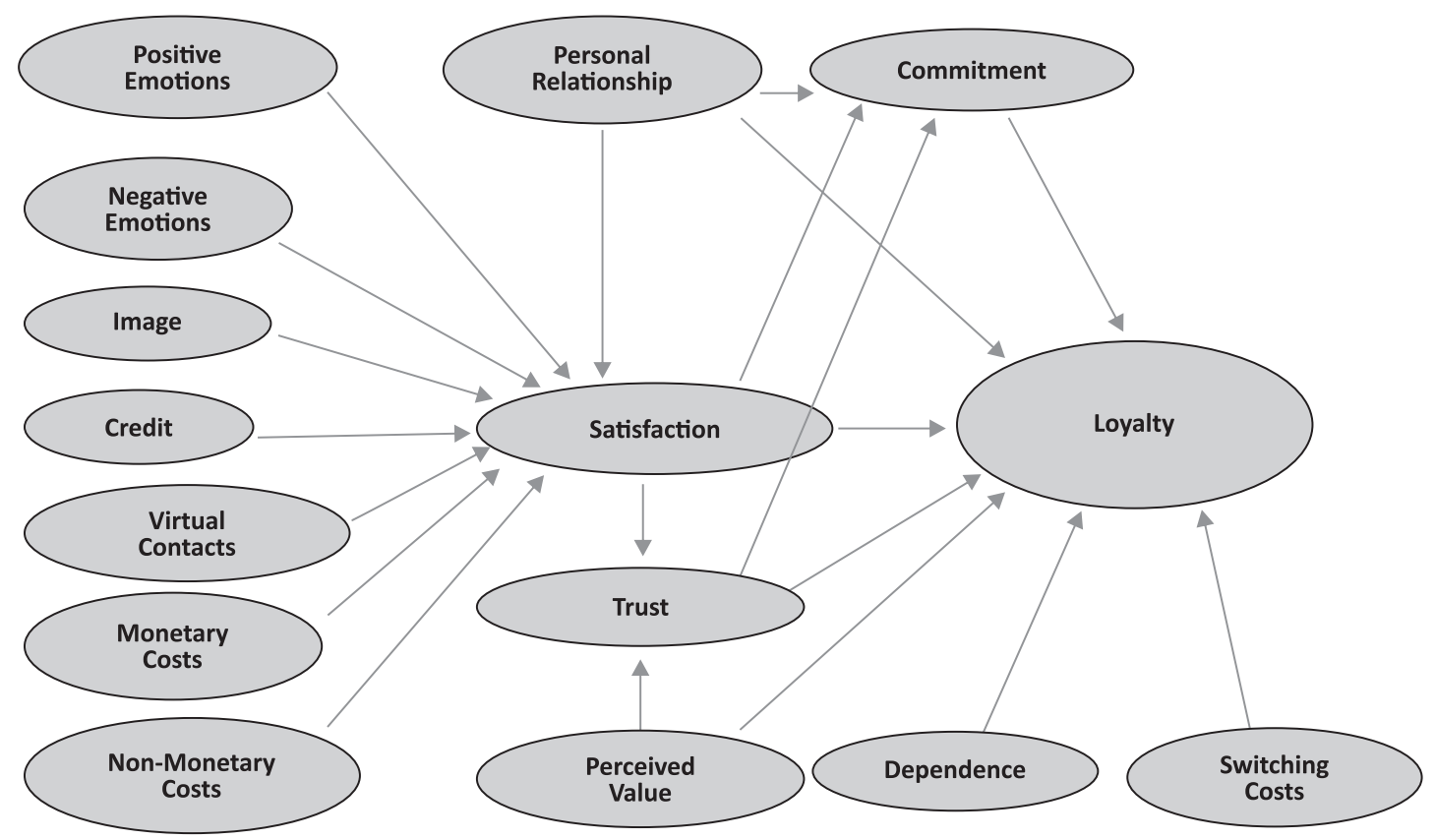

Figure 1 - Conceptual Model

Source: elaborated by the authors (2015).

\section{METHOD}

\subsection{SAMPLE}

In order to test the research hypotheses and the validity of the model under investigation, it was conducted a quantitative cross section study based on a structured questionnaire. Data collection was conducted among individual bank customers with the collaboration of the bank's agencies workers. The research was carried during April 2012. 403 respondents answered the questionnaire under a sequential process. Only 25 customers refused answering the questionnaire. The final sample of 403 individuals, is constituted by $45 \%$ men and $55 \%$ women, aged up to $30,45 \%$, and $55 \%$ more than 30 , and the education levels shows that $40 \%$ are undergraduate and $60 \%$ are graduated.

\subsection{INSTRUMENT}

The variables were operationalized through scales already tested and collected in the literature. The scale to measure emotions (positive and negative) was adapted from Barnes (1997) and Berscheid, Snyder and Omoto (1989). Image was measured using the items from Bloemer and Odekerken-Schröder (2003) and Aydin and Özer (2005). The scale used to measure non personal contacts was based on O'Donnell, Durkin and McCartan-Quinn (2002). The scale to measure credit was adapted from Guarita and Urdan (2006) and Monetary and non-monetary costs were measured based on Guarita and Urdan (2006), supplemented by a set of items inspired by the concept of sacrifice from Holbrook and Corfman (1984). Quality of the relationship with the manager used items developed by Colgate and Lang (2003). Satisfaction was measured with items developed by Hennig-Thurau, Gwinner and Gremler (2002). Trust was measured based on the scale developed by Ball, Coelho and Machas (2004). Af- 
fective Commitment used the scale from Prado and Santos (2003). Switching Costs was measured with items developed by Patterson and Smith (2001). The scale to measure dependence was developed Almeida, Coelho and Coelho (2004) and Holanda (2008). Loyalty was measured based on the scale from Prado and Santos (2003). Finally, perceived value was measured based on the scale developed by Guarita and Urdan (2006).

\subsection{PROCEDURE}

All variables were submitted to exploratory factor and consistency analysis. Table 1 shows that all variables have a high degree of internal consistency (Cronbach's alpha greater than 0.783$)$.

Table 1 - Results of exploratory factor and consistency analysis

\begin{tabular}{lllllll}
\hline Variable & KMO & Alpha & Var. Explained & N & Mean & S.D. \\
\hline Emotions (two dimensions) & 0,851 & & 62,1 & 403 & & \\
Positive Feelings & & 0.824 & & 403 & 3.385 & 0.744 \\
Negative Feelings & & 0.896 & & 403 & 4.201 & 0.812 \\
Image & 0.836 & 0.800 & 53.1 & 403 & 5.134 & 0.889 \\
Credit & 0.713 & 0.826 & 66.05 & 403 & 4.680 & 1.037 \\
Non Presential Contacts & 0.713 & 0.807 & 72.40 & 403 & 3.194 & 1.637 \\
Costs (two dimensions) & 0.713 & & 73.40 & 403 & & \\
Monetary Costs & & 0.855 & & 403 & 3.771 & 1.141 \\
Non-Monetary Costs & & 0.783 & & 403 & 4.204 & 1.277 \\
Relationship Quality & 0.889 & 0.937 & 73.60 & 403 & 4.281 & 1.146 \\
Satisfaction & 0.770 & 0.878 & 66.10 & 403 & 4.870 & 1.153 \\
Trust & 0.677 & 0.837 & 75.10 & 403 & 4.550 & 1.199 \\
Commitment & 0.827 & 0.890 & 69.60 & 403 & 4.319 & 1.189 \\
Switching Costs & 0.677 & 0.820 & 64.22 & 403 & 4.290 & 1.292 \\
Perceived Value & 0,819 & 0,882 & 74,20 & 403 & 4.429 & 1.146 \\
Dependence & 0.735 & 0.803 & 63.13 & 403 & 3.148 & 1.274 \\
Loyalty & 0.858 & 0.928 & 68.16 & 403 & 4.812 & 1.254 \\
\hline Source: & & & & & \\
\hline
\end{tabular}

Source: elaborated by the authors (2015).

\section{RESULTS AND DISCUSSION}

Multiple linear regression was used to test the proposed hypotheses. Even if SEM could be recommended to the hypotheses test, the dimension of the model suggests the need of splitting the global model into partial sub-models to better understand the impacts on each dependent variable. Consequently, MLRM, using a stepwise approach, seems particularly suitable to the statistical modelling. The global model was divided in 4 sub models: Satisfaction; Trust; commitment and Loyalty. The following results, in the table $n^{\circ} 2$, show the determinants of Satisfaction, according to the first sub model. 
Table 2 - Excluded variables: Credit, Contacts and Non-Monetary Costs

\begin{tabular}{lllll}
\hline Satisfaction & $\beta$ & RSquareChange & Signif & VIF \\
\hline Constant & $\mathrm{O}, 438$ & - & - & - \\
Image & 0,428 & 0,449 & 0,000 & 1,836 \\
Relationship Quality & 0,201 & 0,086 & 0,000 & 1,661 \\
Positive Emotions & 0,244 & 0,024 & 0,000 & 1,659 \\
Monetary Costs & 0,167 & 0,021 & 0,000 & 1,301 \\
Negative Emotions & 0,191 & 0,013 & 0,000 & 1,434 \\
\hline $\mathrm{R}^{2}=0,593$ & & & \\
\hline
\end{tabular}

Source: elaborated by the authors (2015).

This sub model explains $59.3 \%$ of the variance of the dependent variable Satisfaction. Credit, Contacts and Non-Monetary Costs seem not to have a significant impact on satisfaction. At the same time, Image, Relationship Quality and Positive Emotions are the variables with the highest impacts on Satisfaction, and those who explain the most of its variance. Even Negative Emotions, unexpectedly, seems to have a positive impact on satisfaction, which shows the importance of emotions. Apparently, positive or negative ones, they can help strengthening the ties with customers by avoiding indifference or a trivial relationship based on trivial contacts. At the same time, Credit and
Costs have a non-significant or residual impact on satisfaction. Satisfaction with banking services seems to be based on image (closer to reputation) and on relationships, and combining rationality with a more emotional approach.

Hypotheses related to Credit, Contacts, Non-Monetary Costs and Negative Emotions were not corroborated, even if Negative Emotions have an impact, but contrary to what could be expected. Hypotheses related to Image, Relationship Quality, Positive Emotions and Monetary Costs were corroborated. The results of the second sub model, concerning Trust, can be seen in the table $n^{\circ} 3$ :

Table 3 - Trust

\begin{tabular}{|lllll|}
\hline Trust & $\beta$ & R2Change & Signif. & VIF \\
\hline Constant & $\mathrm{O}, 581$ & - & - & - \\
Satisfaction & 0,408 & 0,490 & 0,000 & 2,267 \\
Perceived Value & 0,363 & 0,071 & 0,000 & 2,469 \\
Relationship Quality & 0,087 & 0,005 & 0,040 & 1,840 \\
\hline $\mathrm{R}^{2}=0,566$ & & & \\
\hline
\end{tabular}

Source: elaborated by the authors (2015).

This sub model explains $56.6 \%$ of the dependent variable, Trust. Satisfaction and Perceived Value are the variables that explain most of the variance of Trust. Trust seems to be based on rational determinants, which can be explained by the nature of banking services, even if, behind satisfaction, some emotional determinants can be found. Therefore, all hypotheses related to the impacts of Satisfaction, Perceived Value and Relationship Quality, were corroborated. The third sub model, concerns commitment and results can be seen on table $n^{\circ} 4$. 
Table 4 - Excluded variables: Relationship Quality

\begin{tabular}{|lllll|}
\hline Commitment & $\beta$ & R2Change & Signif. & VIF \\
\hline Constant & 0,62 & - & - & - \\
Perceived Value & 0,425 & 0,588 & 0,000 & 2,458 \\
trust & 0,368 & 0,094 & 0,000 & 2,279 \\
Satisfaction & 0,144 & 0,008 & 0,002 & 2,516 \\
\hline $\mathrm{R}^{2}=0,69$ & & & \\
\hline
\end{tabular}

Source: elaborated by the authors (2015).

This model explains $69 \%$ of the variance of the dependent variable, Commitment. Once again, variables with a rational nature like Perceived Value, Trust and Satisfaction are those who explain the variance of Trust. Relationship Quality was excluded. The nature of the industry can explain these results. The hypotheses related to Perceived Value, Trust and Satisfaction where then corroborated. The hypothesis related to Relationship Quality was not corroborated.

Finally, the fourth sub model, related to Loyalty, presented the results showed on table $n^{0} 5$.

Table 5 - Excluded variables: Dependence, Perceived Value, Trust and Relationship Quality

\begin{tabular}{|lllll|}
\hline Loyalty & $\beta$ & R2Change & Signif & VIF \\
\hline Constant & $\mathbf{0 , 0 5 2}$ & - & - & - \\
Satisfaction & $\mathbf{0 , 5 1 8}$ & 0,634 & 0,000 & 2,004 \\
Commitment & $\mathbf{0 , 3 7 8}$ & 0,089 & 0,000 & 2,176 \\
Switching Costs & $\mathbf{0 , 1 4 1}$ & 0,014 & 0,000 & 1,465 \\
\hline $\mathrm{R}^{2}=0,738$ & & & \\
\hline
\end{tabular}

Source: elaborated by the authors (2015).

This last model explains $73.8 \%$ of the variance of the dependent variable, loyalty. Satisfaction, commitment and switching costs explain the loyalty variance and corroborate the related hypotheses. For the contrary, dependence, perceived value, trust and relationship quality were excluded, what means that they do not have a significant impact on loyalty. The hypotheses related to these variables were then, not corroborated, what shows that a rational behaviour seems to prevail in banking services even if, sometimes, non-rational variables seem to impact on mediating variables, like satisfaction. Anyway, it is the rational side that appears as the determinant of the customer's loyalty on banking services.

\section{CONCLUSIONS}

This study aimed to highlight the nature of relationships in an industry where competition is intense and the fight for customer loyalty is fierce. The results of this investigation are broadly in line with the postulates of the theory. Still, some of the presented results seem to contradict it, need some additional explanation. The positive impact of negative emotions on satisfaction, for example, is contrary to what theory suggests. According to Mehrabian and Russell (1974), Havlena and Holbrook (1986), Westbrook (1987), affections or emotions are commonly divided in two independent dimensions: positive and negative emotions. Positive emotions have a positive impact on satisfaction (WESTBROOK, 1987; BLOEMER; ODEKERKEN-SCHRÖDER, 2002) and negative emotions negatively impact on satisfaction (LARAN; ESPINOZA, 2004). This can be explained by any specificity of the sample used or perhaps, negative emotions may give place to a complaint that can be answered positively and be turned into a positive impact on satisfaction. Exchanges between company and customer may contribute to raise positive 
perceptions and to strengthen a relationship, avoiding triviality and indifference and giving content to a relationship. As matter as fact, emotions seem to play a role in banking services, which is commonly characterized by the rationality of its actors.

Anyway, satisfaction has been considered the main driving force and a predictor of customer loyalty. All this makes customer satisfaction a central concern of firms (HESKETT et al., 1994; JONES; SASSER, 1995). Similarly, Mückenberger, (2001, p. 2) suggests that "much of what is researched on satisfaction leads to the suspicion that satisfaction feeds future repurchase intentions, leading to loyalty". This investigation confirms these postulates.

The main drivers of loyalty, Satisfaction, Commitment and Switching Costs, suggest that relationships on the banking services are rather transactional. However, the introduction of Emotions amongst the antecedents of Satisfaction highlights the emergence of a new approach, less rational and more emotional. Still, satisfaction remains as the main driver, which is associated to service quality that seems to be a major determinant of quality, as shown in a recent investigation by Onditi et al. (2012). This transactional approach, where the switching costs role an important role, is probably close to a behavioural approach of loyalty. These costs that the consumer incurs to switch a supplier (LEE; CUNNINGHAM, 2001) mean that his loyalty it is not attitudinal but rather behavioural. These conclusions give a lot of space for a different market approach by the financial institutions and create space for further investigation on the nature of the relationships in this industry.

Finally, the role of emotions has been highlighted, in a market and a business eminently rational. Emotions have significant impacts and somehow unexpected, given what the literature postulates. Emotions are predictors of customer satisfaction in different contexts (WESTBROOK; OLIVER, 1991; OLIVER, 1993; BARNES, 1997; FARIAS; SANTOS, 2000; BLOEMER; ODEKERKEN-SCHRÖDER,
2002) but negative emotions are not expected to have a positive impact on satisfaction.

\subsection{MANAGERIAL IMPLICATIONS}

This investigation identifies the set of variables that seem to lead to customer satisfaction and to customer loyalty. These can be an important basis to set a marketing strategy, focused on the development of profitable long-term relationships and on loyalty. Managers can find here an opportunity to redress their marketing strategies and to rethink the nature of the relationships they maintain with customers. Apparently, these relationships aren't real relationships taking account of the transactional approach that seems to prevail or if they really are, they are rather behavioural and not as stable and profitable as they could be.

At the same time, relationship quality doesn't seem to play an important role. This could mean that customers do not find them relevant or that the actual personal approach is not being properly conducted. Once again, managers can find here a new variable needing to be analysed.

Apparently, the relationships management on banking industry has room to be deepened and managers can, somehow, find ways to redress their strategies taking account the importance that emotions can play, according to the results of this investigation.

\subsection{LIMITATIONS AND FUTURE RE- SEARCH}

This investigation is based on a cross-sectional data collection, based on a non-probabilistic sample. When causal relationships are to be investigated, longitudinal data would help the causality comprehension. Naturally, this gives opportunity for additional investigation. At the same time, the transactional characteristics of the relationships in banking industry or the attitudinal loyalty that seems to prevail gives room to further investigation in this field, looking for the real nature of loyalty and its dri- 
vers. Introducing the role of emotions on the loyalty process is, somehow, another area to be explored in this field.

\section{SERÃO OS CLIENTES BANCÁRIOS VERDADEIRAMENTE LEAIS? UMA INVESTIGAÇÃO ENTRE CLIENTES DOS BANCOS PRIVADOS EM PORTUGAL}

\section{RESUMO}

Este estudo procura identificar e entender os determinantes da satisfação e da lealdade dos clientes na relação entre os clientes e seus bancos. A pesquisa é baseada em uma amostra de 403 clientes particulares de bancos privados no norte de Portugal. A coleta de dados baseou-se em um questionário estruturado, aplicado diretamente aos clientes alvo. Foi adotada a regressão linear múltipla para testar as hipóteses propostas. Em um mercado caracterizado por uma suposta racionalidade, a satisfação foi identificada como a mais importante determinante da lealdade, quer comportamental, quer atitudinal. Os resultados desta investigação mostram que as relações entre os clientes e o seu banco principal, baseiam-se em uma lógica transacional. Elas estão baseadas no valor percebido e nos custos de mudança e a satisfação mantém-se como o principal determinante. Apesar disso, será necessário um estudo mais aprofundado das variáveis psicológicas, como as emoções que mostraram ter um papel significativo na satisfação.

Palavras-chave: Marketing de relacionamento. Lealdade. Satisfação. Comportamento. Bancos.

\section{REFERÊNCIAS}

ADAMSON, I.; SHINE, J. Extending the new technology acceptance model to measure the end-user information systems satisfaction in a mandatory environment: a bank's treasury, Technology Analysis \& Strategic Management, United Kingdom, v. 15, n. 4, p. 441-55, 2003.
ALMEIDA, N.; COELHO, A.; COELHO, F. Determinantes do compromisso nas relações empresariais. In: ENCONTRO NACIONAL DA ASSOCIAÇÃO NACIONAL DOS PROGRAMAS DE PÓS-GRADUAÇÃO E PESQUISA EM ADMINISTRAÇÃO, 28., 2004, Curitiba. Anais... Curitiba: Anpad, 2004. 1 CD-ROM.

ANDERSON, E.; WEITZ, B. Determinants of continuity in conventional industrial channel dyads. Marketing Science, United States, v. 8, p. 310-323, 1992.

ANJOS NETO, M.; MOURA, A. Construção e teste de um modelo teórico de marketing de relacionamento para o setor de educação. In: ENCONTRO NACIONAL DA ASSOCIAÇÃO NACIONAL DOS PROGRAMAS DE PÓS-GRADUAÇÃO E PESQUISA EM ADMINISTRAÇÃO, 28., 2004, Curitiba. Anais... Curitiba: Anpad, 2004. p. 1-15.

AYDIN, S.; ÖZER, G. The analysis of antecedents of customer loyalty in the Turkish mobile telecommunication market. European Journal of Marketing, United Kingdom, v. 39, n. 7/8, p. 910-925, 2005.

BALL, D.; COELHO, P.; MACHAS, A. The role of communication and trust in explaining customer loyalty: an extension to the ecsi model. European Journal of Marketing, United Kingdom, v. 38, n. 9/10, p. 1272-1293, 2004.

BANSAL, H.; TAYLOR, S.; JAMES, Y. ST. Migrating to new service providers: toward a unifying framework of consumers' switching behaviors. Journal of the Academy of Marketing Science, United States, v. 33, n. 1, p. 96-115, 2005.

BARNES, J. Closeness, strength and satisfaction: examining the nature of relationships between providers of financial services and their retail customers. Journal of Psychology \& Marketing, Unites States, v. 14, n. 18, p. 765790, 1997. 
BEERLI, A.; MARTIN, J.; QUINTANA, A. A model of customer loyalty in the retail banking marketing. European Journal of Marketing, United Kingdom, v. 38, n. 1/2, p. 253-275, 2004.

BERRY, L. L. Cultivating service brand equity. Journal of Academy Of Marketing Science, United States, v. 28, n. 1, p. 128-137, 2000.

BERRY, L. L. Relationship marketing of services: perspectives from 1983 and 2000. Journal of Relationship Marketing, Philadelphia, v. 1, n. 1, p. 59-77, 2002.

BERSCHEID, E.; SNYDER, M.; OMOTO, A. The relationship closeness inventory: assessing the closeness of interpersonal relationships. Journal of Personality and Social Psychology, United States, v. 57, n. 5, p. 792-807, 1989.

BHATTACHARYA, C.; BOLTON, R. Relationship market in mass markets. In: JADISH, S.; PARVATIYAR, A. (Ed.) Handbook of relationship marketing. Thousand Oaks C.A.: Sage Publications, 2000.

BLACKWELL, R.; ENGEL, J.; KEGERREIS, $\mathrm{R}$. Word-of-mouth communication by the innovator. Journal of Marketing, United States, v. 33, n. 3, p. 15-19, 1996.

BLOEMER, J.; ODEKERKEN-SCHRODER, G. Store satisfaction and store loyalty explained by customer-and-store related factors. Journal of Consumer Satisfaction, Dissatisfaction and Complaining Behavior, Las Vegas, v. 15, p. 68-80, 2002.

BLOEMER, J.; ODEKERKEN-SCHRODER, G. Antecedents and consequences of affective commitment. Australasian Marketing Journal, Netherlands, v. 11, n. 3, p. 33-43, 2003.

BOWEN, J.; SHOEMAKER, S. Loyalty: a strategic commitment. Cornell hotel \& Administration Quarterly, United States, v. 44, n.5/6, p. 31-46, 2003.

CHAPMAN, J.; WAHLERS, R. A revision and empirical test of the extended price-perceived quality model. Journal of Marketing Theory and Practice, United States, v. 7, n. 3, p. 53-63, 1999.

CHAUDHURI, A.; HOLBROOK, M. The chain of effects from brand trust and brand affect to brand performance: the role of brand loyalty. Journal of Marketing, United States, v. 65 , p. $81-93,2001$

CHOI, K. et al. The relationships among quality, value, satisfaction and behavioral intention in health care provider choice: a South Korean study. Journal of Business Research, United States, v. 57, p. 913-921, 2004.

COLGATE, M.; DANAHER, P. Implementing a customer relationship strategy: the asymmetric impact of poor versus excellent execution. Journal of the Academy of Marketing Science, United States, v. 2, n. 3, p. 375-387, 2000.

COLGATE, M.; LANG, B. Positive and negative consequences of a relationship manager strategy: New Zealand banks and their small business customers. Journal of Business Research, United States, v. 58, n. 2, 1-10, 2003.

COLLIANDER, J.; DÖHLEN, M. Following the Fashionable Friend: The Power of Social Media - Weighing the Publicity Effectiveness Of Blogs versus Online Magazines. Journal of Advertising Research, United Kingdom, v. 51, n. 1, p. 313-320, 2011.

CRONIN, J.; BRADY, M.; HULT, G. Assessing the effects of quality, value, and customer satisfaction on consumer behavioral intentions in service environments. Journal of Retailing, United Kingdom, v. 76, n. 2, p. 193-218, 2000.

CROSBY, L.; EVANS, K.; COWLES, D. Relationship quality in services selling: an in- 
terpersonal influence perspective. Journal of Marketing, United States, v. 54, p. 68-81, 1990.

DAVIES, F. et al. Critical factors in consumer supermarket shopping behaviour: a neural network approach. Journal of Consumer Behavior, Malden, v. 1, n. 1, p. 35-49, 2001.

DAY, G. Diagnosing the product portfolio. Journal of Marketing, United States, v. 41, n. 2, p. 19-38, 1977.

DICK, A.; BASU, K. Customer loyalty: toward an integrated conceptual framework. Journal of the Academy of Marketing Science, United States, v. 22, n. 2, p. 99-113, 1994.

DODDS, W.; MONROE, K.; GREWAL, D. Effects of price, brand, and store information on buyer's product evaluations. Journal of Marketing Research, United States, v. 28, p. 307-319, 1991.

DUNKELBERG, W. How to be successful in small business. Journal of Lending and Credit Risk Management, United States, v. 82, n. 7, p. 53-61, 2000.

DUPONT, R. Relationship marketing: a strategy for consumer-owned utilities in a restructured industry. Management Quarterly, Unites States, v. 38, n. 4, p. 11-16, 1998.

DWYER, F.; SCHURR, P.; OH, S. Developing buyer-seller relationships. Journal of Marketing, United States, v. 51, p. 11-27, 1987.

EL-MANSTRLY, D. et al. An empirical investigation of the relative effect of trust and switching costs on service loyalty in the UK retail banking industry. Journal of Financial Services Marketing, United Kingdom, v. 16, n. 2, p. 101-110, 2011.

FARIAS, S.; SANTOS, R. Modelagem de equações estruturais e satisfação do consumi- dor: uma investigação teórica e prática. Revista de Administração Contemporânea, Rio de Janeiro, v. 4, n. 3, p. 107-132, 2000.

FERRAND, A.; VECCHIATINI, D. The effect of service performance and ski resort image on skier's satisfaction. European Journal of Sport Science, United Kingdom, v. 2, n. 2, p. 1-17, 2002.

FORNELL, C.; WERNEFELT, B. Defensive marketing strategy by customer complaint management: a theoretical analysis. Journal of Marketing Research, United States, v. 24, n. 4, p. 337-346, 1987.

FRANCISCO-MAFFEZZOLLI, E. C. Qualidade do relacionamento, lealdade e resultado financeiro dos usuários de telefonia celular: uma possível contra regra. In: ENCONTRO NACIONAL DA ASSOCIAÇÃO NACIONAL DOS PROGRAMAS DE PÓS-GRADUAÇÃO E PESQUISA EM ADMINISTRAÇÃO, 31., 2007, Rio de Janeiro. Anais... Rio de Janeiro: Anpad, 2007.

GANESAN, S. Determinants of long-term orientation in buyer-seller relationships. Journal of Marketing, United States, v. 58, p. 1-19, 1994.

GANESH, J.; ARNOLD, M.; REYNOLDS, $\mathrm{K}$. Understanding the customer base of service providers: An examination of the differences between switchers and stayers. Journal of Marketing, United States, v. 64, p. 65-87, 2000.

GARBARINO, E.; JOHNSON, M. The different roles of satisfaction, trust and Commitment for relational and transactional consumers. Journal of Marketing, United States, v. 63, p. 70-87, 1999.

GEYSKENS, I. et al. The effects of trust and interdependence on relationship commitment: a trans-atlantic study. International Journal 
of Research in Marketing, Netherlands, v. 13, n. 4, p. 303-318, 1996.

GLANZE, W.; GOLDENSON, R. Longman dictionary of psychology and psychiatry. New York: Longman, 1984.

GREMLER, D.; BROWN, S. The loyalty ripple effect: appreciating the full value of customers. International Journal of Services Industry Management, United Kingdom, v. 10, n. 3, p. 271-291, 1996.

GREMLER, D.; BROWN, S. Service loyalty: antecedents, components and outcomes. In: WINTER EDUCATORS' CONFERENCE, 1998, Dallas. Anais... Dallas: American Marketing Association, 1998. p. 165-166.

GRÖNROOS, C. From marketing mix to relationship marketing: towards a paradigm shift in marketing. Management Decision, United Kingdom, v. 32, n. 2, p. 4-20, 1994.

GRÖNROOS, C. Services management and marketing: a customer relationship management approach. New York: Wiley, 2000.

GUARITA, C.; URDAN, A. Percepções de qualidade, sacrifício e valor: uma investigação em serviços bancários. In: ENCONTRO DE MARKETING DA ANPAD (EMA), 2., 2006, Rio de Janeiro. Anais... Rio de Janeiro: Anpad, 2006. 1 CD-ROM.

GUMMESSON, E. Using internal marketing to develop a new culture-the case of ericsson quality. Journal of Business \& Industrial Marketing, United Kingdom, v. 2, n. 3, p. 2328, 1987.

GUMMESSON, E. Making relationship marketing operational. International Journal of Service Industry Management, United Kingdom, v. 5, n. 5, p. 5-20, 1994.

HART, A.; ROSENBERGER, P. The effect of corporate image in the formation of customer loyalty: an Australian replication. Australasian Marketing Journal, Netherlands, v. 12, n. 3, p. 88-96, 2004.

HAVLENA, W.; HOLBROOK, M. Human factors and ergonomics in consumer product design: methods and techniques. Nova Iorque: CRC Press, 1986.

HENNIG-THURAU， T.; GWINNER， K.; GREMLER, D. Understanding relationship marketing outcomes: an integration of relational benefits and relationship quality. Journal of Service Research, United States, v. 4, n. 3, p. 230-247, 2002.

HESKETT, J. et al. "Putting the Service-Profit Chain to Work". Harvard Business Review, Boston, v. 72, n. 2, p. 164-174, 1994.

HOLANDA, S. Os antecedentes da lealdade no contexto bancário: um estudo com clientes do segmento empresa. 2008. 347f. Dissertação (Doutoramento em organização e gestão de empresas na especialidade de estratégia e comportamento organizacional) - Universidade De Coimbra, Coimbra, 2008.

HOLBROOK, M.; CORFMAN, K. Quality and value in the consumption experience: phaedrus rides again. In: JACOBY, J.; OLSON, J. Perceived quality: how consumers view stores and merchandising. Lexington: Lexington Books, 1984. p. 31-57.

HOWARD, J.; SHETH, J. The Theory of Buyer Behaviour. New York: John Wiley \& Sons, 1969.

HUNT, S. Franchising: Promises, problems, prospects. Journal of Retailing, United Kingdom, v. 53, p. 71-84, 1977.

JACOBY, J.; CHESTNUT, W. Brand loyalty measurement and management. New York: John Wiley, 1978. 
JAFARNEJAD, A.; SHAROUDI, K.; FARZANEH, M. Analysis of the effect of brand personality on customer loyalty to the mellat bank brand in the tehran province. Interdisciplinary Journal of Contemporary Research In Business, United Kingdom, v. 3, n. 9, p. 791-800, 2012.

JOHNSON, M. et al. The evaluation and future of national customer satisfaction index models. Journal of Economic Psychology, Netherlands, v. 22, p. 67-89, 2001.

JONES, T.; SASSER J. Why satisfied customers defect. Harvard Business Review, Boston, v. 73, n. 6, p. 88-99, 1995.

KOTLER, P. Explores the new marketing paradigm. Marketing Science Institute Review, Cambridge, v. 1, p. 1-5, 1991.

KOTLER, P. Administração de marketing: análise, planejamento, implementação e controle. 2. ed. São Paulo: Atlas, 1992.

KUMAR, N.; SCHEER, L.; STEENKAMP, J. The effects of seller fairness on vulnerable resellers. Journal of Marketing Research, United States, v. 32, n. 1, p. 54-65, 1995.

LARAN, J.; ESPINOZA, F. Consumidores satisfeitos, e então analisando a satisfação como antecedente da lealdade. Revista de Administração Contemporânea, Rio de Janeiro, v. 8, n. 2, p. 55- 66, 2004.

LARIVIERE, B. et al. A longitudinal examination of customer commitment and loyalty, Journal of Service Management, United Kingdom, v. 25, n. 1, p. 75-100, 2014.

LEE, M.; CUNNINGHAM, L. A cost/benefit approach to understanding service loyalty. Journal of Services Marketing, United Kingdom, v. 15, n. 2, p. 113-130, 2001.

LEVESQUE, T.; MCDOUGALL, G. Determi- nants of customer satisfaction in retail banking. International Journal of Bank Marketing, United Kingdom, v. 14, n. 7, p. 12-20, 1996.

MADILL, J. et al. Determinants of SME owner's satisfaction with their banking relationships: a Canadian study. International Journal of Bank Marketing, United Kingdom, v. 20, n. 2/3, p. 86-98, 2002.

MARQUES, A. A importância das práticas do marketing relacional na formulação e implementação das estratégias competitivas e a influência destas na lealdade dos clientes e na performance: a investigação de um modelo estrutural no contexto empresarial português. 2003. 537f. Tese (Doutoramento em Organização e Gestão de Empresas, especialização em Estratégia e Comportamento Organizacional) - Faculdade de Economia, Universidade de Coimbra, Coimbra, 2003.

MARR, N.; PRENDERGAST, G. Consumer adoption of self-service technologies in retail banking. International Journal of Bank Marketing, United Kingdom, v. 11, n. 1, p. 3-10, 1993.

MARTIN, C.; GOODELL, P. Historical, Descriptive and Strategic Perspectives on the Construct of Product Commitment. European Journal of Marketing, United Kingdom, v. 25, n. 1, p. 53-60, 1991.

MATTILA, A. Emotional bonding and restaurant loyalty. Cornell Hotel and Restaurant Administration Quarterly, Ithaca, v. 42, n. 6, p. 73-79, 2001.

MEHRABIAN, A.; RUSSELL, J. An Approach to environmental psychology. Cambridge: M.I.T. Press, 1974.

MILLER, D. Handbook of research design and social measurement. 3th. ed. New York: David McKay Co, 1977. 
MITTAL, V.; KUMAR, P.; TSIROS, M. Attribute-level performance, satisfaction, and behavioral intentions over time: a consumption-system approach. Journal of Marketing,United States, v. 63, n. 2, p. 88-101, 1999.

MOORMAN, C.; DESHPANDÉ, R.; ZALTMAN, G. Factors affecting trust in market research relationships. Journal of Marketing, United States, v. 57, p. 81-101, 1993.

MORGAN, R.; HUNT, S. The commitment-trust theory of relationship marketing. Journal of Marketing, United States, v. 58, n. 3, p. 20-38, 1994.

MOURA, H. J. T; GOMES, D.; MOURA, H. J. O efeito da qualidade dos serviços turísticos e da imagem na satisfação do turista de Canoa Quebrada. Revista do Centro de Ciências Administrativas, Fortaleza, v. 11, p. 62-73, 2005.

MÜCKENBERGER, E. O papel da satisfação, confiança e comprometimento na formação de intenções futuras de compra entre clientes com níveis de experiências diferenciados. In: ENCONTRO NACIONAL DA ASSOCIAÇÃO NACIONAL DE PÓS-GRADUAÇÃO E PESQUISA EM ADMINISTRAÇÃO, 25., 2001, São Paulo. Anais... São Paulo: Anpad, 2001. p. $1-15$.

NGUYEN, N.; LE BLANC, G. Corporate image and corporate reputation in customers' retention decisions in services. Journal of Retailing and Consumer Services, United Kingdom, v. 8, p. 227-236, 2001.

O'DONNELL, A.; DURKIN, M.; MCCARTAN-QUINN, D. (2002). Corporate banking in the uk: personal vs remote, interaction. International Journal of Bank Marketing, United Kingdom, v. 20, n. 6, p. 273-284, 2002.

OLIVER, R. Cognitive, affective, and attribute bases of the satisfaction response. Journal of Consumer Research, United States, v. 20, p.
418-430, 1993.

OLIVER, R. Satisfaction: a behavioral perspective on the consumer. New York: Irwin/McGraw-Hill, 1997.

OLIVER, R. Whence consumer loyalty? Journal of Marketing, United States, v. 63, p. 3344, 1999.

ONDITI, A. et al. Implications of service quality on customer loyalty in the banking sector: a survey of banks in homa bay county, Kenya. International Journal of Business and Social Science, Radford, v. 3, n. 21, p. 223- 233, 2012.

PATTERSON, P.; SMITH, T. Relationship benefits in services industries: a replication in a Southeast Asian context. Journal of Services Marketing, United Kingdom, v. 15, n. 6, p. 425-443, 2001.

PATTERSON, P.; WARD, D. Handbook of services marketing and management. California: Sage Publications, 2000.

PRADO, P. A avaliação do relacionamento sob a ótica do cliente: um estudo em bancos de varejo. 2004. 497f. Tese (Doutorado em Administração de Empresas) - Fundação Getúlio Vargas de São Paulo, São Paulo, 2004.

PRADO, P.; SANTOS, R. Comprometimento e lealdade: dois conceitos ou duas dimensões de um único conceito? In: ENCONTRO NACIONAL DA ASSOCIAÇÃO NACIONAL DE PÓS-GRADUAÇÃO E PESQUISA EM ADMINISTRAÇÃO, 27., 2003, Atibaia. Anais... Atibaia: Anpad, 2003. 1 CD-ROM.

PRITCHARD, M.; HAVITZ, M.; HOWARD, D. Analyzing the commitment loyalty link in service contexts. Journal of the Academy of Marketing Science, United States, v. 27, n. 3, p. 333-348, 1999.

QI, Jia-yin et al. Are customer satisfaction and 
customer loyalty drivers of customer lifetime value in mobile data services: a comparative cross-country study. Information technology and Management, Netherlands, v. 13, n. 4, p. 281-296, 2012.

RAVALD, A.; GRONROOS, C. The value concept and relationship marketing. European Journal of Marketing, United Kingdom, v. 30, n. 2, p. 19-32, 1996.

REICHHELD, F. Loyalty-based Management. Harvard Business Review, Boston, v. 71, n. 2, p. 64-73, 1993.

REICHHELD, F. Loyalty and the renaissance of marketing. Marketing Management, United States, v. 2, n. 4, p. 10-17, 1994.

REICHHELD, F.; SASSER, W. Zero clientes perdidos: a qualidade chega aos serviços. In: SVIOKLA, J. J.; SHAPIRO, B. P. Mantendo clientes. São Paulo: Makron Books, 1995. p. 335-350.

REICHHELD, F.; SCHEFTER, P. E-Loyalty: your secret weapon on the web. Harvard Business Review, Boston, v. 78, n. 4, p. 105-113, 2000 .

SHETH, J. Organizational buying behavior: past performance and future expectations. Journal of Business \& Industrial Marketing, United Kingdom, v. 11, n. 3/4, p. 7-24, 1996.

SHETH, J. Relationship marketing: paradigm shift of shaft?, In: SHETH, J.; PARVATIYAR, A. Handbook of relationship marketing. Thousand Oaks: Sage, 2000. p. 609-620.

SHOEMAKER, S.; LEWIS, R. Customer loyalty: the future of hospitality marketing. International Journal of Hospitality Management, United Kingdom, v. 18, n. 4, p. 345-370, 1999.

SIERRA, J.; MCQUITTY, S. Service providers and customers: social exchange theory and service loyalty. Journal of Services Marketing, United Kingdom, v. 19, n. 6, p. 392-400, 2005.

SINGH H., S. The impact of service satisfaction, relational satisfaction and commitment on customer loyalty in logistics outsourcing relationship. Journal of Supply Chain Management Systems, India, v. 4, n. 1, p. 58-71, 2015.

SIRDESHMUKH, D.; SINGH, J.; SABOL, B. Consumer trust, value, and loyalty in relational exchange. Journal of Marketing, United Kingdom, v. 66, p. 15-37, 2002.

SLONGO, L.; MÜSSNICH, R. Serviços ao cliente e marketing de relacionamento no setor hoteleiro de porto alegre. Revista de Administração Contemporânea, Rio de Janeiro, v. 9, n. 1, p. 149-170, 2005.

SOLOMON, M. et al. A role theory perspective on dyadic interactions: the service encounter. Journal of Marketing, United States, v. 49, p. 99-111, 1985.

SOLOMON, M. Customer behavior. Boston: Allyn e Bacon, 1992.

STORBACKA, K.; STRANDVISK, T.; GRONROOS, C. Managing customer relationships for profit: the dynamics of relationship quality. International Journal of Service Industry Management, United Kingdom, v. 5 , n. 5, p. 21-38, 1994.

TAX, S.; BROWN, S.; CHANDRASHEKARAN, M. Customer evaluations of service complaint experiences: implications for relationship marketing. Journal of Marketing, United States, v. 62, n. 2, p. 60-76, 1998.

THUNMAN, C. Corporate banking: services and relationships. The International Journal of Bank Marketing, United Kingdom, v. 10, n. 2, p. 10-16, 1992. 
VERHOEF, P.; LANGERAK, F. Onze preconceitos sobre a gestão das relações com o cliente. Revista Portuguesa e Brasileira de Gestão, Lisboa, v. 1, n. 3, p. 16-23, 2002.

WESTBROOK, R. Product/consumption-based affective responses and postpurchase processes. Journal of Marketing Research, United States, v. 24, p. 258-270, 1987.

WESTBROOK, R.; OLIVER, R. The dimensionality of consumption emotion patterns and consumer satisfaction. Journal of Consumer Research, United States, v. 18, p.84-91, 1991.

WINSTANLEY, M. What drives customer satisfaction in commercial banking? Commercial Lending Review, Boston, v. 12, n. 3, p. 36-42, 1997.

WOODRUFF, R. Customer value: the next source for competitive advantage. Journal of the Academy of Marketing Science, United States, v. 25, n. 2, p. 139-154, 1997.

ZEITHAML, V. Consumer perceptions of price, quality, and value: a means-end model and synthesis of evidence. Journal of Marketing, United States, v. 52, p. 2-22, 1988.

ZEITHAML, V. A.; BERRY, L. L.; PARASURAMAN, A. The behavioral consequences of service quality. Journal of Marketing, United States, v. 60, p. 31-46, 1996. 